\title{
Tobacco experimental model to induce urinary bladder neoplasms
}

\section{Modelo experimental de tabagismo para indução de neoplasia da bexiga urinária}

José Alexandre Colli Neto'; José Hélıo Zen Júniori; André Del Negro, ACBC-SP2; Nelson Adami Andreollo, TCBC-Sp; Marina Rachel Araujo ${ }^{3}$; Alfio José Tincan $\left.\right|^{2}$

\section{A B S T R A C T}

\begin{abstract}
Objective: to develop an experimental model of exposure to tobacco burning (cigarette) products to assess the effects of its chronic use in relation to cancers of the bladder. Methods: the animals were chronically exposed to the burning tobacco products in a semi-open chamber to simulate smoking. Thirty young Wistar rats were divided into two groups: one with 20 animals simulating smoking for six months, and ten not exposed control animals for the same period. After exposure by inhalation of cigarette smoke, animals were euthanized and subjected to histopathological study of the bladder wall. Results: no tumor was found but mild and non significant alterations. The studies of hemo-oximetry (carboxyhemoglobin and methemoglobin) and the concentration of carbon dioxide (CO2) confirm that the animals were exposed to high concentrations of tobacco smoke and its derivatives. Conclusion: no bladder mucosal neoplasia was found in the pathological study of animals. The developed experimental models were highly efficient, practical and easy to use and can be used in other similar studies to determine the harmful effects caused by smoking.
\end{abstract}

Key words: Animal Experimentation. Inhalation. Smoking. Rats. Urinary bladder neoplasms.

\section{INTRODUCTION}

C igarette smoking is associated with several diseases and is responsible for approximately five million deaths a year worldwide and about 200,000 in Brazill. It is considered by the World Health organization (WHO) the leading cause of preventable death ${ }^{2}$. Many diseases are caused by smoking, this being because the tobaccorelated diseases often have some latency to develop symptoms, generating certain negligence in relation to risk.

Bladder cancer is a malignancy that affects mainly white men on the sixth and seventh decades of life and may develop from the transitional cells of the urothelium. Half of all diagnosed cases are associated with smoking habit and, moreover, the disease is usually related to use of sweeteners and analgesics, and to occupational factors. Of diagnosed cases, $90 \%$ are urothelial carcinomas of the bladder (in the three outer layers of the organ) and, among them, $75 \%$ are superficial. Only $5 \%$ to $8 \%$ of cases type squamous cell carcinomas, which can invade deeper layers, and $2 \%$ are adenocarcinomas, which have greater potential for local invasion. It is the second most common type of cancer in the genital region. In more advanced cases it may invade the outer wall of the bladder and reach other organs. As the epithelium that lines the urinary bladder and part of the urethra is the same, tumors that develop in these structures have very similar characteristics ${ }^{3}$. To reduce the risk of death by this disease, early diagnosis is very important ${ }^{4}$.

It is known that smoking is the greatest risk factor for bladder cancer, with a two to four times higher risk than non-smokers, although only half of patients with bladder cancer are smokers.

The aim of this study was to develop an experimental model of exposure to the burning tobacco products (cigarette) to assess the effects of its chronic use in relation to cancers of the bladder.

\section{METHODS}

Thirty young, randomly chosen, male Wistar rats weighing between 300 and $400 \mathrm{~g}$ were studied. The animals were kept in common cages for the species, lined with wood shavings and kept in the animal house at the Department of Experimental Medicine and Surgery. The research was approved by the Ethics Committee on Animal Experimentation (Protocol 14411/2008).

The cigarettes were employed to study the possible histological changes in animals from chronic

1. School of Medicine, UNICAMP; 2. Department of Surgery, UNICAMP; 3. Center for Experimental Medicine and Surgery, UNICAMP. 
exposure and contained the following specifications: Tar $10 \mathrm{mg} /$ cigarette; Nicotine $0.8 \mathrm{mg} /$ cigarette; carbon monoxide (CO) $10 \mathrm{mg} / \mathrm{c}$ igarette. We offered water ad libitum and each animal received a specific number, marked on the body. The animal groups were as follows: Group I - 20 animals subjected to daily inhalation of cigarette smoke in the exposure chamber. Animals in this group were subjected to smoke exposure (eight cigarettes per day) for six months, a period considered sufficient to cause changes in the mucosa, since, on average, a month of the animal's life is approximately five years of human life $^{5}$. In the exposure chamber we also carried out the counting of the particles of CO; Group II - Ten control animals just receiving water and food ad libitum.

Exposure to smoke was conducted in a chamber as described by Wright et al. ${ }^{6}$ and modified by Biselli et al. ${ }^{7}$ (Figure 1), and comprised an airtight container for receiving the animal, coupled with a cylinder of compressed air, whose particles were accelerated under a laminar flow system with low pressure, dependent on flow and acceleration. Upon reduction of the tube cross diameter, by an interposed pipette, compressed air was accelerated (steadily, but acquiring a higher speed as it passed through the tip of the pipette). When the pressure at this point dropped below atmospheric pressure produce the desired effect was achieved: aspiration of cigarette smoke on the other end of the system (Venturi effect).

A compressed air tank pressurized the chamber through an air conduit coupled to the system described above to obtain a larger amount of smoke produced by burning cigarettes. Inside the chamber the lit cigarettes were set with the filter end connected to another air conduit that lead the smoke directly to the exposure chamber, thus obtaining a significant increase in the amount of smoke produced and inhaled by the animals.

During the observation period the animals received standard chow diet and their weights were monitored monthly.

In two stages of the study we carried out hemooximetry of the animals to evaluate the effectiveness of the chamber.

The measurement was performed in two animals exposed to smoke and one control animal, those exposed being assessed in two stages: five minutes and ten minutes of exposure. Items assessed were: hemoglobin $(\mathrm{Hb})$ oxyhemoglobin $\left(\mathrm{HBO}_{2}\right)$, carboxyhemoglobin $(\mathrm{HbCO})$, methemoglobin (MetHb), total oxygen (total $\mathrm{O}_{2}$ ), after five minutes of exposure ( $\left.5^{\prime}\right)$ and after ten minutes of exposure $\left(10^{\prime}\right)$.

The concentration of carbon dioxide $\left(\mathrm{CO}_{2}\right)$ in the interior of the chamber after lighting the third cigarette was measured daily for two weeks.

The rats were euthanized by anesthesia with intravenous thiopental in lethal dose of $2 \mathrm{ml} / \mathrm{kg} /$ weight. The organ for histopathologic study was obtained from dissection of the bladder, removing it completely. The specimens were fixed in formalin for 24 hours and then stored in $70 \%$ alcohol solution and fixed in paraffin blocks. The serial sections were prepared on slides and the fragments stained with hematoxylin and eosin. The statistical Chi-square test was used and the results considered significant when generating $\mathrm{p}<0.05$.

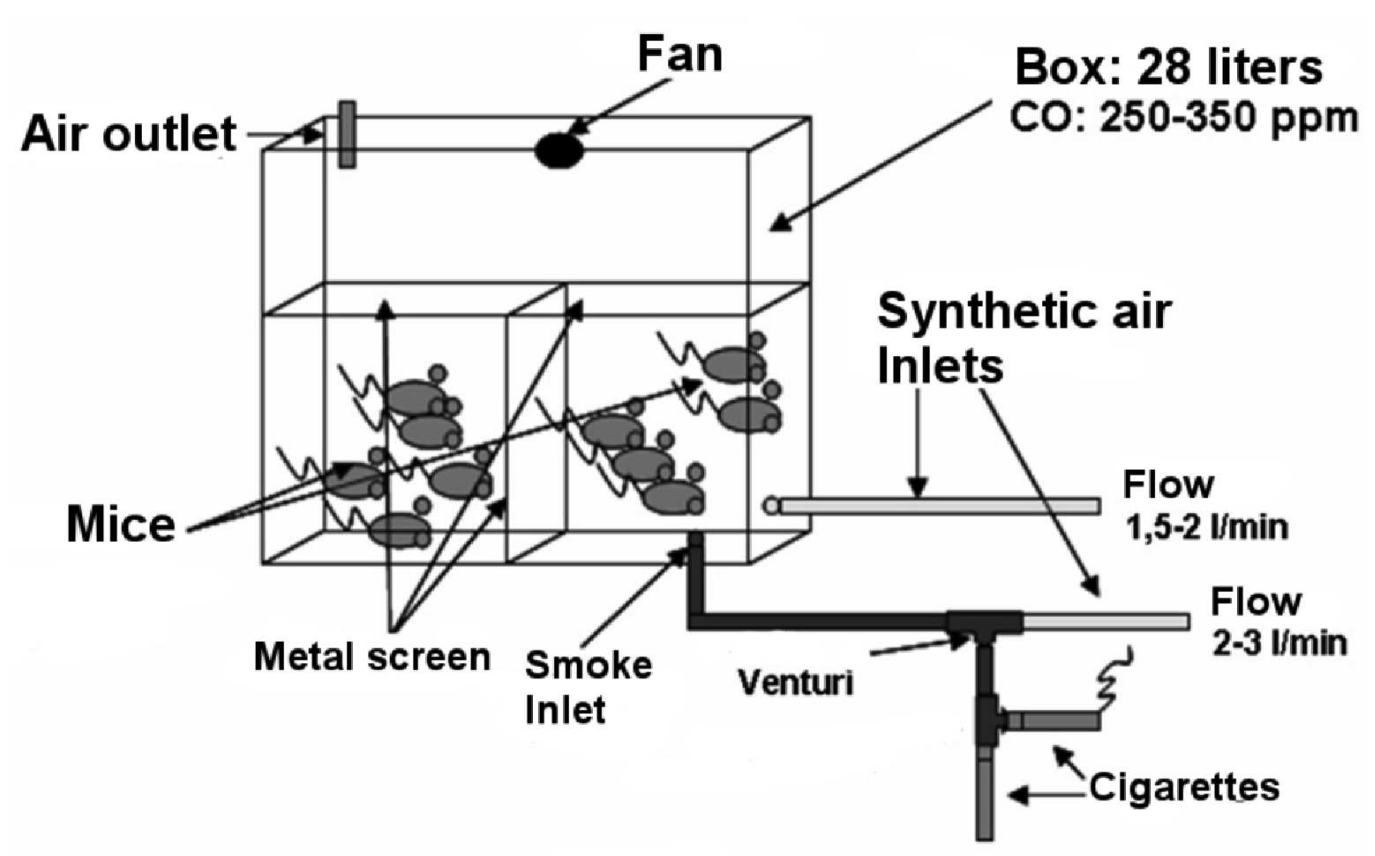

Figure 1 - Chamber of exposure to cigarette smoke (courtesy of Biselli et al. ${ }^{7}$ ). 


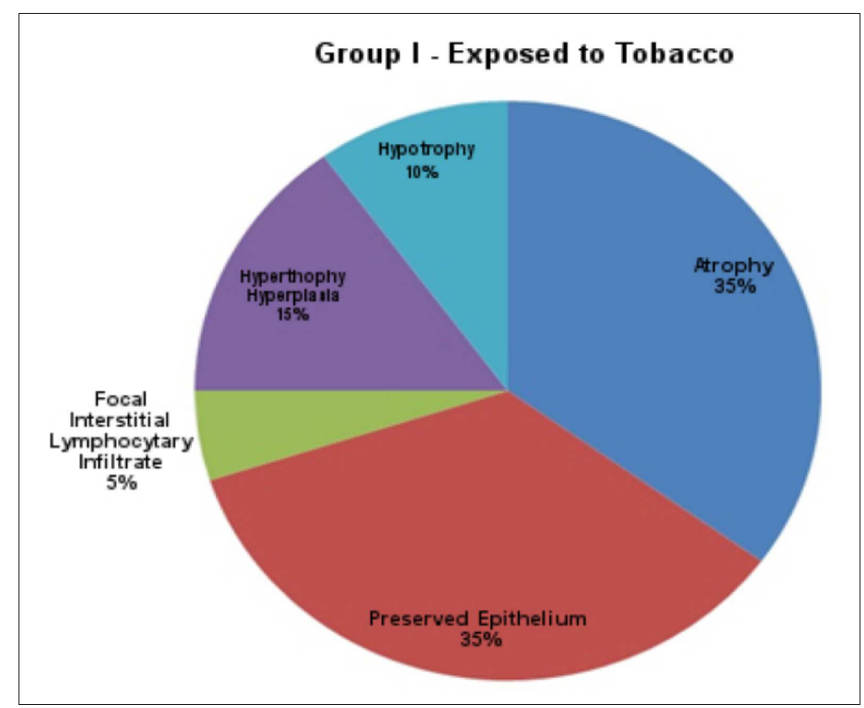

Figure 2 - Results of histopathological analysis.

\section{RESULTS}

\section{Weight of animals}

No significant changes were detected in animal weights between the groups, which ranged from 300 to $460 \mathrm{~g}$, and all gained weight during the experiment.

\section{Hemo-oximetry}

There was no variation in hemoglobin and total oxygen $(p>0.05)$, but oxyhemoglobin, carboxyhemoglobin, methemoglobin varied. Hemoglobin was elevated at five and ten minutes of smoke exposure compared with control animals $(p<0.005)$. Values of carboxyhemoglobin and methemoglobin were significantly elevated when compared with controls after ten minutes of exposure $(p<0.05)$, carboxyhemoglobin suffering a sharp rise.

\section{$\mathrm{CO}_{2}$ Concentration}

The result of the concentration of carbon dioxide $\left(\mathrm{CO}_{2}\right)$ in the camera always showed a measurement greater than 999 parts per million (raised above the threshold to the point that the machine displayed the message "out of limit" - value Limit: 999ppm). Therefore, the $\mathrm{CO}_{2}$ concentration due to cigarette burning in the exposure chamber was significant.

\section{Histopathology}

No neoplastic lesions were recorded in the animals of both groups.

The results of the histology revealed seven animals with atrophy, two with hypotrophy and three hyperplasia associated with hypertrophy of the bladder epithelium (Figure 2). In three cases these results showed moderate hypertrophy of the muscular layer of the organ. Despite adequate exposure time, the changes were not marked on any of the parameters. This can be evidenced in the analysis of the control group ( $p>0.05)$.

In this group, $50 \%$ of the samples presented with atrophy and $50 \%$ hypertrophy with hyperplasia of the bladder epithelium, without gross alterations. Therefore, neoplastic lesions were not recorded in the experiment.

\section{DISCUSSION}

Tobacco contains more than thirty known carcinogens, mostly composed of polycyclic aromatic hydrocarbons and nitrosamines. The older studies indicated that $20-30 \%$ of bladder cancers in women were caused by smoking. Nowadays, it is known that this rate rose to $50 \%$ among women and remained at that value for men ${ }^{8}$. Mortality in the U.S. for this type of cancer is 7.7 and 2.2 per 100,000 men and women, respectively 9 .

There are few experimental models of exposure to cigarette smoke, although most of them are used for mice. Wistar and Sprague-Dawley rats, rabbits, dogs and guinea pigs have been used in research with different cameras and under different exposure protocols, although an ideal model does not yet exist. D' Agostini et al. ${ }^{10}$ studied the protector effect of $\mathrm{N}$-acetyl-cysteine in Sprague-Dawley rats exposed to cigarette smoke in a TE-10 exposure machine.

Shapiro proposed an airtight chamber with high exposure to tobacco content for the study of chronic obstructive pulmonary disease in mice ${ }^{11}$. His model has been used and modified by Biselli et al. ${ }^{6}$, who studied the effect of exposure of cigarette smoke and diesel oil residue in the lungs of mice.

Table 1 - Hemo-oximetry of animals exposed to smoke at 5 and 10 minutes, and control animal.

\begin{tabular}{lccccc}
\hline & $\mathrm{Hb}(\mathrm{g} / \mathrm{dl})$ & $\mathrm{HbO}_{2}$ & $\mathrm{HbCO}$ & $\mathrm{MetHb}$ & Total $\mathrm{O}_{2}$ \\
\hline Rat 1 $-5^{\prime}$ & 18.9 & 58.1 & 0.2 & 0.8 & 15.1 \\
Rat 1 - 10' & 18.9 & 58.6 & 6.8 & 1.4 & 15.2 \\
Rat 2 - 5' & 19.7 & 60.5 & 0.2 & 0.7 & 15.2 \\
Rat 2 - 10' & 19.7 & 60.4 & 7.1 & 1.5 & 15.4 \\
Control & 19.8 & 45.9 & 0.4 & 0.6 & 14.4 \\
\hline
\end{tabular}


The present study aimed at the development of experimental models for carcinogenesis in the urinary bladder in animals exposed to cigarette smoke.

After analyzing the results, we infer that the weight of the animals increased in the isolated analysis of each individual, with no changes, showing that tobacco exposure did not interfere with the normal development of animals.

The hem-oximetry, held at two times during the experiment, made it possible to prove by analysis of carboxyhemoglobin and methemoglobin that the system was effective to provide the animals with the inhaling substances originating from the burning cigarette inside the exposure chamber. It was also demonstrated that the dose was directly dependent on the exposure time. Therefore, it can be stated that the system was efficient in simulating smoking, the time of exposure being its critical feature. Intoxication by $\mathrm{CO}$ and $\mathrm{CO}_{2}$ was so high that caused the death of three animals at the beginning of the experiment, confirming the high intensity of exposure of animals to tobacco substances and its burning byproducts.

Histopathological examination showed mild and not significant changes due to the small number of animals in the sample. Further experiments are needed in the future, with longer exposure and more animals.

Although neoplasia was not observed in the bladder mucosa of animals, the developed and implemented experimental model was effective, practical and easy to use and can be used in other similar studies to determine the harmful effects caused by smoking.

\title{
R E S U M O
}

\begin{abstract}
Objetivo: desenvolver modelo experimental de exposição aos produtos da queima do tabaco (cigarro) para avaliar os efeitos do seu uso crônico em relação às neoplasias de bexiga. Métodos: Os animais foram expostos cronicamente aos produtos da queima do tabaco em câmara semi-aberta para simular o tabagismo. Trinta ratos jovens da raça Wistar foram distribuídos em dois grupos: um com 20 animais simulando o tabagismo por período de seis meses, e um com dez animais controle sem exposição por igual período. Após exposição por inalação da fumaça do cigarro, os animais foram eutanasiados e submetidos a estudo histopatológico da parede da bexiga. Resultados: Não foi encontrada neoplasia e sim alterações leves e não significativas. Os estudos da hemo-oximetria (carboxiemoglobina e metemoglobina) e da concentração de dióxido de carbono $\left(\mathrm{CO}_{2}\right)$ confirmam que os animais foram expostos a altas concentrações da fumaça do tabaco e de seus derivados. Conclusão: No estudo anatomopatológico dos animais não foi encontrada neoplasia na mucosa da bexiga. Os modelos experimentais desenvolvidos foram altamente eficientes, práticos e fáceis de usar podendo ser empregados em outros estudos semelhantes para determinar os efeitos nocivos causados pelo tabagismo.
\end{abstract}

Descritores: Experimentação animal. Inalação. Tabagismo. Ratos. Neoplasias da bexiga urinária.

\section{REFERENCES}

1. Escobar Arriaga E, Pérez Bautista O, Ramírez Venegas A, Sansores Raúl $\mathrm{H}$. Efecto del daño de vías dopaminérgicas mesencefálicas en la conducta adictiva al tabaco: revisión generadora de una hipótesis. Rev Inst Nal Enf Resp Mex. 2007;20(1):56-63.

2. Castro MG, Oliveira MS, Moraes JFD, Miguel AC, Araújo RB. Qualidade de vida e gravidade da dependência de tabaco. Rev Psiquiatr Clín. 2007;34(2):61-7.

3. Portillo Martín JA, Rado Velázquez MA, Gutiérrez Baños JL, Correas Gómez MA, Hernández Rodríguez R, del Valle Schaan Jl, et al. Upper urinary tract tumours. Actas Urol Esp. 2004;28(1):7-12.

4. Brazil. Ministry of Health. Federal Coordination. Brazilian National Cancer Institute (INCA). Prevention and Surveillance Coordination. Tobacco and other cancer risk factors control division. Rio de Janeiro: INCA; 2005.

5. Quinn R. Comparing rat's to human's age: how old is my rat in people years? Nutrition. 2005;21(6):775-7.

6. Wright JL, Churg A. Cigarette smoke causes physiologic and morphologic changes of emphysema in the guinea pig. Am Rev Respir Dis. 1990;142(6 Pt 1):1422-8.

7. Biselli PJC. Efeito da exposição à fumaça de cigarro e ao resíduo de óleo diesel (ROFA) em pulmões de camundongos C57/B16 [tese]. São Paulo: Universidade de São Paulo, Faculdade de Medicina: 2008.

8. Freedman ND, Silverman DT, Hollenbeck AR, Schatzkin A, Abnet CC. Association between smoking and risk of bladder cancer among men and women. JAMA. 2011;306(7):737-45. Erratum in: JAMA. 2011:306(20):2220.

9. Howlader N, Noone AM, Krapcho M, Neyman N, Aminou R, Waldron W, et al, editors. SEER Cancer Statistics Review, 19752008, National Cancer Institute. Bethesda. 2011. Disponível em http://seer.cancer.gov/csr/1975_2008/

10. D'Agostini F, Balansky RM, Izzotti A, Lubet RA, Kelloff GJ, De Flora S. Modulation of apoptosis by cigarette smoke and cancer chemopreventive agents in the respiratory tract of rats. Carcinogenesis. 2001;22(3):375-80.

11. Shapiro SD. Animal models for COPD. Chest. 2000;117(5 Suppl 1):223S-7S.

Received on 30/09/2012

Accepted for publication 22/12/2012

Conflict of interest: none.

Source of funding: none.

\section{How to cite this article:}

Colli Neto JA, Zen Júnior JH, Del Negro A, Adreollo NA, Araújo MR, Tincani AJ. Tobacco experimental model to induce urinary bladder neoplasms. Rev Col Bras Cir. [periódico na Internet] 2014;41(1). Disponível em URL: http://www.scielo.br/rcbc

\section{Address for correspondence:}

José Alexandre Neto Colli

E-mail: josealexandrecolli@gmail.com 